\title{
Promoting Social Justice by Rejecting Genetic Reductionism: A Challenge for Developmental Science
}

\author{
Richard M. Lerner \\ Institute for Applied Research in Youth Development, Tufts University, Medford, Mass., USA
}

Developmental science seeks to describe, explain, and optimize the lives of individuals and groups across the human life span. Today, convergence between models, reflecting relational developmental systems concepts of mutually influential personcontext relations, and research, for example, from fields such as epigenetics, evolutionary biology, social genomics, and life-span development, indicates that relative plasticity (the potential for systematic change in the relations between individuals and their settings) exists across the human life span [e.g., Meaney, 2010, 2014; Misteli, 2013]. The presence of such plasticity means that cognition, emotions, motivation, personality, or behaviors are not fixed; development is possible across ontogeny. Plasticity means as well that what we currently see as characterizing much of contemporary society (particularly in the United States) - racial, ethnic, social class, sexual orientation, and gender disparities; unequal life chances predicated on unjust allocation of rights and resources; the psychologically and socially "suffocating" burden of living under conditions of prejudice and discrimination; and the growing divides of privilege, power, and life potentials - need not characterize the future of modern societies.

Developmental scientists can contribute mightily to addressing these injustices and, as well, to promoting opportunities for social cohesion and multi-sector collaborations that may, eventually, dissolve the plethora of divides that detract from creating a nation that lives by its vision of liberty and justice for all. We can devote our science to designing, implementing, and evaluating community-based programs, or to informing or assessing the outcomes of social policies, that are aimed at enhancing the outcomes of the mutually influential relations between individuals and their contexts, relations that constitute the fundamental process of development across the life span. This optimism is bolstered by important innovations in developmental methodology that enable the relational developmental system to be studied in integrated, change-sensitive ways.

In short, the knowledge and skill sets of developmental scientists can contribute to creating among citizens optimism that actions can be formulated to successfully enhance the lives of diverse individuals. In significant and timely ways, developmental scientists can help give people hope that there are evidence-based actions that can

\footnotetext{
KARGER 125\% @ 2015 S. Karger AG, Basel

E-Mail karger@karger.com www.karger.com/hde
}

Richard M. Lerner

Institute for Applied Research in Youth Development 301 Lincoln Filene Building, Tufts University Medford, MA 02155 (USA)

E-Mail richard.lerner@tufts.edu 
be taken to address the frustrations, outrage, and deeply felt fears for the well-being and healthy development of diverse individuals, and for the institutions of democracy, civil society, and social justice. Such optimism may energize individuals to seek the resources and collaborations needed to proactively address the challenges facing our nation's diverse youth, families, and communities, challenges underscored in the wake of the events surrounding the deaths of African Americans Michael Brown and Eric Garner at the hands of police, and by what appears to many Americans as the egregious failures of our justice system and the partisan polarization and inaction of our political institutions.

Of course, not all developmental scientists are actively engaged in such policy- or program-relevant actions. However, there is a way in which all developmental scientists may apply their knowledge to enhance the likelihood that there will be a social and political context conducive to enhancing social justice and to decreasing discriminatory-based disparities within America. A key set of actions that all developmental scientists can take is to speak out against the flawed reasoning and research of people using counterfactual models of genetic reductionism to claim that policies and programs aimed at promoting social justice are inefficient, inappropriate, or even doomed to fail because of irremediable biological constraints on the cognitive, emotional, motivational, and behavioral characteristics of some groups of youth.

There are many examples of such fallacious reasoning and research being used to make scientifically ill-founded recommendations about social policies and child development programs. They are associated with reductionist formulations, such as parental investment theory within evolutionary psychology [e.g., Ellis, Schlomer, Tilley, \& Butler, 2012], or behavior genetic or sociobiological models of intellectual differences among racial groups [e.g., Jensen, 1969; Rushton, 2000]. The dimensions of bad science reflected in such genetic reductionist ideas are legion, going well beyond logical problems and misrepresentations of fundamental features of genetic functioning. These problems involve claims that conflate description and explanation, equate purported analogy with biological homology, neglect problems of data analysis and interpretation and inappropriately infer homogeneity and stationarity of data sets (when human development is fundamentally idiographic and changing), ignore low levels of variance and weak effect sizes in promulgating generalizations about genetic influences on behavior, or hold that genes or the brain alone are responsible for development.

Assertions derived from genetic reductionist ideas also ignore the abundant and burgeoning evidence that genes are outcomes of evolutionary processes and not bases of them. There is a similarly large and convincing literature that genetic function is a relatively plastic outcome of mutually influential relations among genes and the multiple levels of the context within which they are embedded: cellular and extracellular physiological processes, psychological functioning, and the physical, social, and cultural features of the changing ecology that, together, create epigenetic change [e.g., Cole, 2014; Slavich \& Cole, 2013]. These data make fanciful, at best, the Kipling-like "Just-So Stories" about how genes function. For instance, the imagined stories of how the genes that (purportedly) afforded survival on the African savannah now, millennia later, explain sexual and reproductive behaviors among contemporary girls of color [e.g., Ellis et al., 2012] stretch credulity beyond reasonable bounds, especially when current biological data indicate that epigenesis may create changes in the role of genes in person-context relations that may persist across generations. 
Nevertheless, at this writing there have been recent instances of Op-Ed pieces in major newspapers [Belsky, 2014], or of books written by well-credentialed science writers [e.g., Wade, 2014], that advocate without adequate evidence that biological reductionist ideas should be applied to programs and policies. These erroneous applications of fallacious ideas create social mischief, at best, and racial, ethnic, class, gender, etc. divisiveness and social turmoil, at worst [e.g., Feldman, 2014]. These recommended uses of bad science reinforce fears of institutionalized racism in America and further the societal marginalization of minority groups; these implications of their recommendations are never publically considered by those who promulgate these flawed extensions of counterfactual genetic reductionism.

Developmental scientists must speak out, individually and collectively - through opinion pieces, editorials in leading journals, consensus documents from leading scholarly organizations, and testimony and advocacy at local, state, and national political levels. There is abundant and compelling evidence that the work of developmental scientists can help heal and enhance people and institutions. Working with colleagues, students, neighbors, and family members, developmental scientists may use their knowledge and skills to help optimize the lives of all citizens and contribute to social justice. The time for this work is now, and the places for such actions are our homes, workplaces, schools, faith institutions, and communities.

\section{Acknowledgements}

The preparation of this article was supported in part by grants from the John Templeton Foundation. References to the theoretical, methodological, and empirical ideas discussed in this article may be found in Volume 1 of the 7th edition of the Handbook of Child Psychology and Developmental Science [Overton \& Molenaar, 2015, published by Wiley], but some representative references are cited in the present article. I am grateful to Jennifer Agans, Milena Batanova, Kristina Callina, Lisette DeSouza, Justin Lerner, Megan Mueller, and Christopher Napolitano for their comments.

\section{References}

Belsky, J. (2014, November 30). The downside of resilience. New York Times, Sunday Review, p SR4.

Cole, S.W. (2014). Human social genomics. PLoS Genetics, 10, 1-7.

Ellis, B.J., Schlomer, G.L., Tilley, E.H., \& Butler, E.A. (2012). Impact of fathers on risky sexual behavior in daughters: A genetically and environmentally controlled sibling study. Development and Psychopathology, 24, 317-332.

Feldman, M. (2014). Echoes of the past: Hereditarianism and a troublesome inheritance. PLoS Genetics, 10, e1004817.

Jensen, A.R. (1969). How much can we boost IQ and scholastic achievement? Harvard Educational Review, 39, 1-123.

Meaney, M. (2010). Epigenetics and the biological definition of gene x environment interactions. Child Development, 81, 41-79.

Meaney, M. (2014, October 10). Epigenetics offer hope for disadvantaged children [Children and Family: Web log post, in German]. Retrieved from http://childandfamilyblog.com/epigenetics-offer-hopedisadvantaged-children/.

Misteli, T. (2013). The cell biology of genomes: Bringing the double helix to life. Cell, 152, 1209-1212.

Rushton, J.P. (2000). Race, evolution, and behavior (2nd special abridged edition). New Brunswick, NJ: Transaction.

Slavich, G.M., \& Cole, S.W. (2013). The emerging field of human social genomics. Clinical Psychological Science, 1, 331-348.

Wade, N. (2014). A troublesome inheritance: Genes, race and human history. New York, NY: Penguin Books. 